\title{
Mitigation of Indonesia Concurrent Election Dispute Settlement in 2024
}

\author{
Ari Wirya Dinata \\ Constitutional Law \\ Bengkulu University \\ Bengkulu, Indonesia \\ aridinata@unib.ac.id
}

\author{
M. Yusuf Akbar \\ Constitutional Law \\ Bengkulu University \\ Bengkulu, Indonesia \\ yusufakbarbkl@gmail.com
}

\begin{abstract}
Based on Constitutional Court verdict Number 55 / PUU-XVII / 2019 which was released out on February 26, 2020, ordering the implementation of concurrent general elections. In 2019 was the first experience of holding general elections simultaneously with 5 (five) boxes and 5 (five) types of ballots, namely the presidential election, the election for members of the People's Representative Council, the Provincial Regional People's Representative Council, the Regency /City Regional People's Representative Council, and Regional Representative Council simultaneous nationally. This simultaneous general election system is extremely complicated in the process. It is not only complex but also takes a lot of victims based on experience in 2019 due to the large workload of the organizers. The massiveness and size of this democratic party caused difficulties for the organizers of both the general election commission, the election supervisory body, and the honorary council of election organizers in carrying out their duties. Not to mention, in 2024 the simultaneous general elections in Indonesia will not only be elections at the national level but also include elections at the regional level to elect governors, regents / mayors. Every general elecation event always ends in a dispute over the results of the general election. The Constitutional Court as a state institution that had the authority to settle disputes over the results of general elections (Article $24 \mathrm{C}$ of the 1945 Constitution) will certainly reap the same impact if all disputed results are submitted to the Constitutional Court simultaneously. Meanwhile, the Constitutional Court is the last resort in upholding electoral justice. This paper uses a normative juridical research approach to concepts, theories and legislation. The data used are secondary data with primary, secondary and tertiary legal materials. This paper tries to answer the challenges of concurrent election dispute resolution in 2024 by providing an idea of limiting margins to file a lawsuit, and a dismissal process that involves academics at the local level to handle disputed cases of results in regional head elections both governors, regents or mayors.
\end{abstract}

Keywords- Concurrent Election 2024, Dispute Settlement, Democracy

\section{INTRODUCTION}

The issue of democratic development and democratization in a country is almost certainly related to general elections. Because elections are one of the important tools to measure the growth and development of procedural and substantial democracy in a country. If the implementation of elections can take place fairly and democratically, then democracy in a country has grown perfectly [1].

Indonesia is a country that has implemented democracy since the beginning of its independence. It is traced from the provisions of Article 1 paragraph (2) of the 1945 Constitution which states that "Sovereignty is in the hands of the people and is carried out by the People's Consultative Assembly". This provision means that Indonesia adheres to a system of representative democracy or indirect democracy.

According to Jimly Asshiddiqqie, this provision means that: First, in fact, it is the people as the source of power, the people are also the people who directly and indirectly become the administrators and administrators of the state and in the end it is for the benefit of all the people that the administration of the state is actually intended [2]

As Grotius stated that the highest power to govern is called sovereignty. Sovereignty is held by people who are not subject to other powers, so that they cannot be contested by human will. Furthermore, Jean Bodin argues that sovereignty is a power that overcomes citizens and subordinates, even above the law, or in other words, Bodin said that sovereignty is a full and lasting power that belongs to a republic [3].

Over time, the dynamics and development of Indonesian constitutional law shifted from adopting an indirect democracy to a direct democracy. It is shown from the provisions of Article 1 paragraph (2) of the 1945 Constitution after the amendment which reads "Sovereignty is in the hands of the people and carried out according to the Constitution". certain procedures 
[4]. In addition, this article also changes the paradigm of democracy, which means that Indonesia changes its democratic system from indirect to direct.

Since then, the model for filling the office of president, which was originally carried out by the People's Consultative Assembly, has become directly elected by the people (Article 6A of the 1945 Constitution). One indicator of a country that adheres to a presidential system of government is the direct presidential election. Because the presidential election through the MPR so far is thicker with the nuances of a country that adheres to a parliamentary system of government. As stated by Saldi Isra in the presidential government system there are at least 2 elections, namely the presidential election and the legislative election.

The arrangement of the electoral system in Indonesia always changes from time to time in every election implementation. In the process of making changes to regulations, every election has legal political dynamics, namely political, economic, social and cultural backgrounds for the birth of the Election Law [1].

Before the amendment to the constitution, there was no regulation on the institutionalization of elections in the 1945 Constitution, however in the third amendment to the 1945 Constitution, there was a strengthening of democratic institutions with the emergence of Chapter VIIB on General Elections [5]. Provisions for the implementation of elections in Indonesia are regulated in article $22 \mathrm{E}$ of the 1945 Constitution. Article $22 \mathrm{E}$ paragraph (1) states that elections are a 5-year political agenda that is carried out in accordance with the principles of Direct, General, Secret-Free, Honest and Fair (LUBER \& JURDIL). Meanwhile, Article 22 E paragraph (2) of the 1945 Constitution provides an interpretation that elections are held every 5 years to elect members of the DPR, DPD, and DPRD as well as the President and Vice President.

So far, this provision has been interpreted as holding separate elections, namely the legislative election first, then followed by the presidential election. So that one of the conditions for presidential nomination depends on the votes obtained by political parties in the previous legislative elections. It is the calculation and conversion of votes in the legislative election that is then used as a condition for presidential candidacy (presidential threshold).

Because the President must reach a certain threshold set out in the law, sometimes the president has to form a coalition in running for office. The consequence of a coalition in practical politics is the formation of seats of power in state institutions and ministries. In fact, the presidential threshold is not known in the 1945 Constitution, therefore maintaining that threshold is tantamount to maintaining constitutional defects in the presidential election process [6]. Even today, this defect is still maintained in the practice of the presidential election and is further strengthened through various decisions of the constitutional court

This condition was formed because the political and legal architecture of Indonesian parties and elections was built on the foundation of a multi-party and presidential system. Where according to Scott Mainwaring's research, the combination of these two elements often ends in failure or political chaos. Therefore, an idea is needed to mitigate other threats that arise as a result of legal disputes and electoral practices in Indonesia [7].

In a multi-party system, Mirriam Budiardjo said that no single party was strong enough to form a government on its own. Because, in a general election with a multiparty system, it will be difficult to bring up a party that gets an absolute majority [8].

In the practice of state administration in Indonesia, the opposite is true. A presidential system that should place the president as an executive who cannot be influenced by the actions of the legislature, in fact makes the president have to form a coalition with other parties to get the support of the legislature [8].

So, to avoid the fraudulent practices that are intertwined in the presidential nomination process and the presidential election, then there is a test of various provisions regarding the procedures and methods of conducting elections that have existed so far. Efforts to change the system have been carried out through various constitutional means of reviewing the Election Law. first, the idea of abolishing the presidential nomination threshold that could cause the president to be held hostage in the formation of a post-victory cabinet, second, by engineering electoral law by no longer separating the implementation of legislative and executive elections. So, there is no longer any reason to form a coalition of political parties based on pragmatic interests. This provision was later strengthened in the Constitutional Court's decision Number 14/PUU$\mathrm{XI} / 2013$ concerning the unification of the legislative and executive elections.

Even in the decision of the Constitutional Court Number 55/PUU-XVII/2019, it actually strengthens and unites the general election, which can be carried out simultaneously, not only between elections at the central level to elect the legislature and president but also regional head elections and regional legislatures.

This condition will seem good in preventing practical political practices as mentioned in the explanation above, and even seem to save the use of the state budget for holding elections. but learned from the implementation of the first simultaneous elections, namely 2019. Where at that time there were still national simultaneous elections that had taken a lot of victims and had difficulties in resolving electoral disputes, including disputes over election results conducted by the Constitutional Court. 
So that for the most part, holding simultaneous national and local elections in 2024 will for the first time provide challenges and complexities of higher intensity than the 2019 elections. Moreover, the current difficulties, due to the COVID-19 pandemic causing restrictions on physical activities outside so that it will complicate the preparation stage. and campaign.

Learn from the holding of regional simultaneous elections in the past COVID-19 which left the problems of violations and conflicts. So it is possible that the same mode and pattern will happen again in the 2024 simultaneous elections and it is even certain that the wave of electoral fraud and violations will be massive and 2 times larger because it coincides with the implementation of the legislative and presidential elections.

Alex Hadenis said that an election is called democratic if it has "meaning" or meaning. The meaning of democracy refers to the three criteria for conducting elections, namely openness, accuracy and effectiveness. These three criteria must not only be met in the an sich election process but also in the resolution of electoral disputes as residues of the democratic process [9].

Electoral justice cannot be negated in the conduct of elections. both justice in the administration of elections (procedural justice) and substantive justice. According to IDEA International as quoted by Refly Harun, there are 15 benchmarks for the implementation of a secret, free, fair and honest election, namely: [10]

- The legal framework should be structured in such a way that it is non-dual, understandable and transparent, and should address all elements of the electoral system needed to ensure democratic elections;

- The choice of electoral system should ensure international standards of elections and democracy. Such as election frequency choice, election unit organization;

- The legal framework for elections should ensure that the boundaries of electoral units are designed in such a way as to achieve the goal of equal weight for each vote to the highest possible degree to achieve effective representation;

- The legal framework should ensure that all eligible citizens are guaranteed the right to vote universally and fairly;

- The legal framework should require that EMBs be established and function in a manner that ensures the independent and fair conduct of elections;

- The legal framework should require transparent and accurate storage of voter lists;
- The legal framework should ensure that all political parties and candidates can compete in elections on the basis of fair treatment;

- The legal framework should ensure that every political party and candidate enjoys the right to freedom of expression and freedom of assembly and access to voters;

- The legal framework should ensure all candidates have access to a balanced media;

- The legal framework should ensure transparent, accountable and balanced election funding;

- The legal framework should ensure access in the voting process;

- The legal framework should ensure that all votes are properly counted;

- Legal frameworks that protect the integrity and transparency of elections

- The legal framework that provides access to effective election inspectors;

- The legal framework should provide for effective legal mechanisms and remedies for compliance with the law and enforcement of suffrage. It should also explain the penalties for election violations.

As mentioned in point 15 of the concept of electoral justice initiated by IDEA International, the existence of an election administration structure followed by an effective settlement mechanism is a condition sine qua non. So, it is necessary to reformulate the legal political options for resolving electoral disputes (election residues) that exist in Indonesia if there is a change to the electoral system which today adheres to national and local simultaneousness.

Traced from 1945 to 2020, Indonesia has held 12 general elections (without regional head elections). The first general election was in 1955 to elect members of the DPR and constituent members, six times during the New Order era (1971, 1977, 1982, 1987, 1992, and 1997) and five times during the reform period (1999, 2004, 2009, 2014 and 2019). Election methods and procedures have also changed a lot because the legal politics of elections from time to time has always experienced significant changes. 12 elections that have been held, so that many Election Laws or the legal basis for elections are made [11].

TABLE I. ELECTION LAWS AFTER THE AMENDMENT OF THE 1945 CONSTITUTION

\begin{tabular}{|c|c|l|}
\hline No & $\begin{array}{c}\text { General } \\
\text { Elections }\end{array}$ & \multicolumn{1}{c|}{ Regulations } \\
\hline & 2004 & $\begin{array}{l}\text { 1) Law No. 12 of 2003 concerning General } \\
\text { Elections for Members of DPR, DPD and } \\
\text { DPRD. } \\
\text { 2) Law Number 23 of 2003 concerning the }\end{array}$ \\
\hline
\end{tabular}




\begin{tabular}{|c|c|}
\hline & $\begin{array}{l}\text { General Election of President and Vice } \\
\text { President. }\end{array}$ \\
\hline 2009 & $\begin{array}{l}\text { 1) Law Number } 10 \text { of } 2008 \text { concerning } \\
\text { Elections for Members of DPR, DPD, and } \\
\text { DPRD; } \\
\text { 2) Law Number } 42 \text { of } 2008 \text { concerning the } \\
\text { Election of the President and Vice } \\
\text { President. }\end{array}$ \\
\hline 2014 & $\begin{array}{l}\text { 1) Law No. } 8 \text { of } 2012 \text { concerning General } \\
\text { Elections for Members of the People's } \\
\text { Representative Council, Regional } \\
\text { Representative Council, and Regional } \\
\text { People's Representative Council. } \\
\text { 2) Law Number } 42 \text { of } 2008 \text { concerning } \\
\text { General Election of President and Vice } \\
\text { President }\end{array}$ \\
\hline 2019 & $\begin{array}{l}\text { Law Number } 7 \text { of } 2017 \text { concerning General } \\
\text { Elections }\end{array}$ \\
\hline
\end{tabular}

As previously mentioned, prior to the Constitutional Court's Decision Number 14/PUU-XI/2013 which interpreted Article 22E paragraph (2), the election to elect members of the legislature was conducted before the Presidential and Vice-Presidential elections. However, after a quo Constitutional Court decision, the implementation of the General Election as stated in Article 22E paragraph (2) shall be carried out simultaneously. The practice of this simultaneous general election was carried out for the first time in the 2019 general election

From the table above, it can be interpreted that the design of the time for holding elections developed in line with the decision of the Constitutional Court which interpreted the holding of elections simultaneously. The Constitutional Court's decision, which is accommodated in Law Number 7 of 2017 concerning General Elections, signifies a new phase of simultaneous elections, namely the legislative and presidential elections simultaneously. This concept was first implemented in 2019 known as the 5-box election.

The Constitutional Court's decision number 55/PUU-XVII/2019 regarding the examination of the Election Law and the Election Law The Court provides an open legal policy for legislators to choose 5 models of Simultaneous Election options. However, if viewed from the original intents of the amendments to the 1945 Constitution of 1999-2000, there were 7 electoral models discussed, one of which was the separation of the Presidential and Vice-Presidential Elections from the legislative elections, but in its decision the Court only gave 5 choices and freedom for legislators to choose other models. during the presidential election, the DPR and DPD are not separated. Because the Court believes that the simultaneous election of the President, DPR and DPD will strengthen the presidential system.

If we look at the fulfillment of civil political rights and justice in the last 5 square elections in 2019, the fire is still far from being roasted. This is because in its implementation it leaves a dark record starting from taking lives due to the heavy workload for the implementation, it is recorded that 894 officers died and
5,175 officers were sick, as well as records of law enforcement and dispute resolution. Although the record number of disputed results at the Constitutional Court in 2019 has decreased compared to the PHPU cases in 2014. Namely, in 2014 there were 902 PHPU applications with details of 461 PHPU for Regency/City Elections, 181 Provincial Legislative Election, 225 legislative election of the people's representative council and 34 Regional Representative Council Legislative Elections, While PHPU in the 2019 Election there were 470 PHPU applications with details of 215 PHPU applications at the Regency/City DPRD Legislative Elections level, 110 Provincial Legislative Elections, 71 at the DPR level, and 11 at the DPD level (data: Initiative Code).

However, this number has not been accompanied by the number of PHPU-D cases. Meanwhile, in 2024, elections will be held simultaneously at the central and local levels. The design unites 2 simultaneously, namely elections at the central level and elections at the regional level, of course, adding to the complexity of dispute resolution on election results in the Constitutional Court, especially the characteristics of the PHPU case which must be resolved in a fast time (speedy trial). This simultaneous double will have logical consequences with challenges and dynamics with a magnitude 2 times greater than in 2019. Moreover, the ongoing COVID-19 disaster will add to the complexity of the next 2024 election stage.

The same challenges and problems will repeat themselves and even have the potential to cause 2 times greater implications if there is no management engineering for holding simultaneous elections in 2024 and management engineering for handling election disputes Sarah Birch of the University of Essex in her research report (she compared observer reports on 136 elections held between 1995 and 2006 stated and found that the most frequently used tactic to manipulate elections was to change electoral laws as a means of deterring opposing candidates or creating opportunities for fraud in the constitution are difficult to penetrate. However, when it comes to honest, fair and democratic elections, the Election Law is only one of the instruments available to make it happen [12].

The existence of a dispute resolution mechanism with an authorized institution is actually intended to guarantee the citizens' right to vote. Regarding institutions that can be used as an alternative for resolving election disputes, International IDEA mentions that there are at least 4 institutions, namely [13]:

- Administrative body, namely the election management body in charge of organizing elections;

- Judicial Body namely:

a. General court which is a branch of judicial power or 
b. Independent courts, such as constitutional councils or tribunals, state administrative courts or special electoral courts that are not under traditional legislative, executive or judicial powers

- Legislative body, namely the people's representative council itself or part of the council (eg committee); and

- International bodies, namely bodies that have jurisdiction in countries that recognize the existence of regional and international courts that issue binding decisions and must be implemented by competent national bodies

The four institutions are alternative institutions that can be entrusted with the authority to resolve election disputes in various forms. The choice of the institution in question will greatly depend on the needs of holding elections in each country. Choosing only one of the existing institutions to resolve all types of disputes, for example submitting it to the judiciary alone or to an election management body specifically assigned to do so, can be done as long as the mechanism is effective in safeguarding citizens' voting rights

Election cases in Indonesia have many dimensions of problems. ranging from administrative disputes, election criminal disputes, organizers ethics, and election results disputes. In Indonesia, election dispute resolution is diffuse (decentralized) rather than centrally carried out by a single institution (centralized). For example, related to fraud in general elections carried out by election participants, the action and supervision is carried out by the Election Supervisory Body (Bawaslu), related to administrative errors (election mal-administration), the State Administrative Court is given the authority to adjudicate, while the District Court for administrative matters related to election crimes such as destruction of ballot boxes and others. Meanwhile, for disputes over election results, authority is given to the Constitutional Court as mandated by Article 24 C paragraph (1) of the 1945 Constitution. Meanwhile, disputes relating to violations of ethics for administrators are tried by DKPP.

This complicated electoral dispute resolution system in Indonesia will have an impact on the fulfillment of electoral justice. As cited by IDEA International, electoral justice is more likely from the perspective of a fair electoral settlement system, in other words, electoral justice in IDEA's view is demarcated at the level of the electoral law problem solving system in order to uphold citizens' suffrage.

The holding of the upcoming 2024 general election is a means of proving by the state of its ability or even showing its inability to handle and solve problems in the implementation of elections simultaneously. Considering the complexity of organizing elections in 2024 which combines elections at the central and regional levels simultaneously. This will affect the effectiveness of the performance of the organizing institutions and the resolution of election disputes. For this reason, it needs to be mitigated in a constitutional design of an election dispute resolution model that is able to accommodate the national and regional simultaneous election styles in 2024. so that simultaneous elections can achieve justice both procedurally and substantively.

\section{ARRANGEMENTS FOR THE SETTLEMENT OF ELECTION DISPUTES BY TYPE IN THE ELECTION LAW AND OTHER LAWS AND REGULATIONS}

Various institutions set standards for democratic elections.One of them is IDEA which mentions 15 elements, namely: (1) structuring the legal framework; (2) the electoral system: (3) boundary delimitation, districting ordefining boundaries of electoral units: (4) the right to vote and to be elected; (5) electoral management bodies; (6) voter registration and voter registers; (7) ballot access for political parties and candidates; (8) democratic electoral campaigns; (9) media access and freedom of expression; (10) campaigns finance and expenditure; (11) balloting; (12) votes counting and tabulating; (13) role of the representatives of the parties and candidates; (14) electoral observers; and (15) compliance and enforcement of electoral law.

In connection with the 15th element above, according to an international standard the legal framework must be:

"... provide that every voter, candidate and political party has the right to lodge a complaint with the competent electoral management bodies (EMB) or court when an infringement of electoral rights is alleged to have occurred. The law must require that the appropriate EMB or court render a prompt decision to avoid aggrieved party losing his / her electoral right. The law must provide a right of appeal to an appropriate higher level of EMB or court with authority to review and exercise final jurisdiction in the matter. The decision of the court of last resort must be issued promptly" [14].

Disputes can be divided into two, namely: (1) disputes in the electoral process (especially those that occur between election participants or between candidates) which has been handled by the election supervisory committee (Bawaslu); and (2) election dispute or dispute. In accordance with the provisions of the 1945 Constitution, UU Elections, and the Constitutional Court Law; the authority to settle disputes over election results lies in the hands of the Constitutional Court. Actually, there is another third dispute, which is not regulated in the Law, namely: (3) disputes over participants or candidates objecting to the KPU determination or KPUD. A number of problems occurred in the elections and the pilkada occurred as due to a lack of rules that need to be improved in the future. One problem that often arises is the organizer's decision 
elections regarding election participants and presidential candidates (as well as candidates District head). The failure of the candidates participating in the election as well as the presidential candidates and regional heads as a result of election organizer decisions is still happening [15].

Election result disputes or better known as disputes election results are disputes between election participants and the KPU as election administrators regarding determination of national votes election results by the KPU, including disputes between the participants in the General Election of the Council Aceh People's Representative (DPRA) and Regency / Regency People's Representative Council Cities in Aceh and the Independent Election Commission (KIP). This was confirmed in Article 1 point 17 of the Regulation of the Constitutional Court (PMK) of the Republic of Indonesia Number 14 of 2008 concerning Guidelines for Proceeding in Disputes over Results Election for members of the DPR, DPD and DPRD [16]

Based on Law Number 7 of 2017 concerning General Elections, there are several things related to election process disputes, including:

Art. 466 provides that:

"Election process disputes include disputes between election participants and participant disputes elections with election organizers as a result of the issuance of KPU decisions, KPU decisions provincial, district / city KPU decisions" [17]

Article 470 Paragraph 1 provides that:

"Disputes over the electoral process through state administrative courts include disputes that arise in the field of state administration, Election between candidates for members of DPR, DPD, Provincial DPRD, DPRD regencies/cities, or political parties as candidates for Election Contestants, or prospective pairs of candidates with KPU, KPU Provincial, Regency / City KPU, as a result of the issuance of KPU decisions, KPU decisions Province, Regency/City $K P U^{\prime \prime}[17]$

Regarding the dispute resolution of the electoral process at Bawaslu, the settlement of election process disputes at State Administrative Court, procedures for resolving election process disputes through the Administrative Court State Enterprises, the Special Election State Administrative Council contained in Article 467 to Article 472 Law Number 7 Year 2017 Concerning General Elections. Election result disputes include disputes between the KPU and election contestants regarding decisions national election results as stipulated in Article 473 of the Law Number 7 of 2017 concerning General Elections, then the procedure for resolving election result disputes contained in Article 474 and Article 475 of Law Number 7 of 2017 concerning General Elections. Disputes that are often referred to are the same as conflicts according to Ali Achmat :

"A dispute is a conflict between two or more parties that originates from perceptions which is different about an interest or property that can give rise to legal consequences for both" [18].

Based on the two definitions of the dispute above, it can be broken down into several elements, including: 1) the presence of two or more parties; 2) there is a relationship or the same interest to a certain object; 3 ) there are contradictions and differences in perceptions; and 4) legal consequences.

Disputes resolved by the Constitutional Court are disputes concerning determination of the results of general elections conducted nationally by the General Election Commission influences: the election of a candidate for member of the Regional Representative Council; determination of the pairs of candidates who enter in the second round of the General Election of the President and Vice President and the election of the presidential candidate pair and the Vice President, and obtaining seats for political parties participating in general elections in an electoral district [15]. There are three types of Constitutional Court decisions for disputes over the results of the 2004 General Election, namely: (1) petition not acceptable; (2) the application is rejected; and (3) the request is granted. The application was declared no received is a petition that fails out of substance, with various possible causes, viz because the application does not meet administrative requirements; is not within the authority of the Constitutional Court; or because it does not significantly affect the position of the existing seat acquisition. The application was declared rejected if the application meets administrative requirements, the case is within the authority of the Constitutional Court, and it has a significant effect on the existing seat acquisition position, but the arguments put forward are not proven. Meanwhile, the petition is declared granted if the submitted application complies administrative requirements, under the authority of the Constitutional Court, have a significant effect on the acquisition position existing seats, and the arguments put forward are proven [15].

There is a common understanding that electoral dispute resolution processes and mechanisms are Effective electoral dispute resolution mechanisms and processes are a sine qua non for honest and fair elections. There are three fundamental issues in resolving election disputes, namely: (1) The validity of the results, and thus the right to test or contest election results; (2) Action administration of election administrators to correct or resolve a problem, that is questioned by justice seekers whose electoral rights have been violated; and (3) Criminal charges for those who commit criminal offenses in the electoral process [15]. 


\section{RECORDS OF THE 2019 SIMULTANEOUS ELECTION AND ENFORCEMENT OF ELECTION LAW AND ITS RESOLUTION}

The simultaneous general election on April 17, 2019 took place relatively smooth, safe, and peaceful. As a competition democratic, in general a new concurrent electoral process the first time it was held it can be said takes place relatively freely, democratically, fairly, and honestly. Referring to international standards of election administration, the 2019 Concurrent Election can be said to have fulfilled almost all the standards required for the holding of elections that is free, fair, and democratic [19]. The community concern of possible emerge conflicts with ethnic, religious, race, and between groups (SARA) as a result of the spread Resentment and the politicization of religion did not occur relatively during the voting and counting process. Unrest limited scale had spread in a number of places in Jakarta such as around the Election Supervisory Body Building (Bawaslu), Slipi, Petamburan, and Tanah Abang before and at the time The General Election Commission (KPU) announces the election results 2223 May 2019, but can be muted and relatively not disrupt the process and the next stages of the election.

However, it should be noted immediately, first, the 2019 elections left deep sorrow for Indonesia because of the death of hundreds of officers Voting Organizing Group (KKPS) and other officials. Not less than 527 KPPS officers died, 11,239 people fell ill during the process voting until the 2019 Election vote count. It is assumed that the main factor behind the sad news that hurt the Election 2019 is due to fatigue due to heavy weight of the officers and apparatus in conducting guard elections in order the five-year "party of democracy" can take place according to plan, i.e., finished one day on that day same. As is known, the elections were simultaneously carried out with five letters votes at the same time are far more burdensome for the KPPS officers and other apparatus than the previous elections.

Second, in the context of the presidential election, it emerged an accusation from one of the participants camps, namely the bearer of candidate pair 02 Prabowo Subianto-Sandiaga Uno, ongoing fraud structured, systematic, and massive (TSM) that is profitable nominee 02 Joko Widodo-Ma'ruf Amin camp. Despite the accusation's fraud cannot be proven by the stronghold legal team 02 and the Constitutional Court has decided against it lawsuits on allegations of fraud of a TSM nature, some of the supporters of Prabowo-Sandi do not appear to be fully accept the political reality. This phenomenon certainly not healthy for a democratic culture because of how even a democratic system requires the presence of a mutual atmosphere trust various interested parties in it.

To make arrangements regarding enforcement Law on Election, the concept has been determined from the start an appropriate model for handling election violations prevailing regulations in Indonesia, so all the regulations related will refer to the handling model. Some matters that must be agreed upon include the following [20]:

a) Types of violations: Most election laws contain more detailed sections on the form of violations Elections and the provision of sanctions. Will it be distinguished actions against the law and the practice of money politics (corruption), provisions on campaign funds, which are the sanctions different.

b) Inquiries and investigations: It is necessary to determine the institution responsible for form of objection and determining whether an action against the law has happened or not.

c) Prosecution: Regulations should give authority to agreed institutions to investigate cases related to complete elections.

d) Punishment: Giving strict and clear sanctions must be able given to violators of the Election Law and Election Penalties.

Election law enforcement practices in Indonesia so far it shows that the issue of law compliance and there are still many shortcomings in enforcement of election regulations and weakness. Therefore, it is necessary to build a system better and more appropriate election law enforcement democratic election standards. Apart from learning from experience itself, the system building needs to also be studied on the experiences of other countries with problems the same one. Based on the evaluation and empirical implementation of the implementation of the 2019 Election, there are several summaries input related to regulations on election law enforcement that must be repaired.

- Legislation must be clear in mechanisms that provide a greater sense of justice to the parties in resolving Election violations. Based on international standards, the legal framework must be regulating sanctions for violations of the Election Law. Every provisions of articles established for legal purposes must reflect the objectives of drafting a law. For example, one of the objectives of election law enforcement is efforts to protect the integrity of the Election. Therefore, legislators must regulate strictly fraudulent practices or criminal violations of the Election with prohibits treatment that can hinder the essence Free and fair elections [21].

- With regard to election criminal offenses, adjustments need to be made criminal law nomenclature. Need to change the term 'Election criminal offenses' with the term' criminal offense Elections'. Election crime is a crime must be severely punished because it involves use voting rights and citizens' right to vote, not just an offense that is simply aberrant or infringing statutory provisions. Settings Election crimes only focus on election crimes. 
- The laws and regulations for the elections in the future must re-clarify the meaning of Election administration violations. Administrative offenses can be distinguished into two major groups, as seen from the impact the process of implementing the Election or the results of the Election, namely minor administrative violations and violations heavy administration. The impact affects sanctions which will be given.

- It is necessary to specifically regulate the handling time limitation violations of both administrative and election crimes so as not to cause a dilemma for law enforcement agencies when in receiving, examining, deciding cases violation at the recapitulation stage of calculation of results vote acquisition.

- Election violation regulations do not just protect election participants, but also implementing agencies and voter. The provisions concerning election violations are addressed to protect the election process from all form's offense. Therefore, it needs to be set in every order criminal threat related to the election are linked with administrative sanctions in order to increase deterrent effect on the perpetrators.

- The politics of law in the preparation of the design of the enforcement system Election law needs to be directed at an optimal level administrative errors due to consequences arising from Election legal action in order to improve the rights of election participants and the public and to restore integrity of the election process and results; optimizing deterrent effect; as well as pushing the system simple, fast, and election law enforcement low cost.

- Encourage the prioritization of the administrative sanctions approach in enforcing the Election law in order to recover the rights of election participants and the community as well as increasing deterrent effect for offenders. The form of sanction is directed to punishments that reduce the rights of participants Election in following certain stages, eliminating the right to participate in elections, the right to determined as an elected candidate, even the right to following the next election. Prioritization of approach this administrative sanction does not mean eliminating the provisions of criminal threats, but simplifies criminal provisions and enforce the procedure law in under the Criminal Procedure Code regime. Thus, the enforcement process criminal law in elections need not be limited by tight deadlines.

- So that the process of resolving Election violations is complete it is fast, final and binding it needs to be established that the agency is involved in problem solving Election laws don't have to be too many. Therefore, it encourages Election law enforcement arrangements the unification of the Election justice system under the authority of one institution only, and consequently eliminates competence of other judicial institutions to examine and decide cases related to elections. Of course, The judicial system referred to here is a system the judiciary outside the settlement of election results disputes which has been regulated in the 1945 Constitution. So there needs to be clearer and more defined arrangements and definitions on the inside Election Law on concepts and powers Bawaslu in resolving Election violations.

- In every stage of the Election, it is necessary to make an inventory serious that can be made the norm be Election acts or election acts. Offense serious among others are: manipulation of voter data on voter registration stage; supporting data manipulation, candidate data at the registration stage and participant determination Elections; violence, threats, intimidation, bribery (money politics), insults, office seats and facilities for campaign purposes, irregularities campaign funds at the campaign stage; choose two times, cause the right to vote, do fraud in counting, which hinders voters, do violence, threats, intimidate people vote or not, money politics, bribery election administrators and counting manipulation sound. What needs to be studied more deeply is the approach Election law enforcement is currently still dominant in the form of criminal sanctions, in fact the law is unable to act effectively deterrent effect. Apart from that the construction of the enforcement system design Election criminal law is still very complex, multi-layered and mutually oriented. Therefore, it needs to be studied how the law can be enforced managed to deter those who carried out the attack.

\section{THE WEAKNESS OF CURRENT ELECTION SETtLEMENT DisPute RESOlution PROCESS AND THE ALTERNATIVE RESOLUTION DISPUTE RECOMMENDATION}

The weakness of current election settlement dispute resolution process in Indonesia for example verdicts on election cases that overlap between judicial institutions are due to the construction of laws No.7 of 2017 concerning Elections provides electoral law enforcement models through various judicial institutions namely the Supreme Court and the Constitutional Court, even non-court institutions, namely Bawaslu and DKPP. Where are the respective institutions the judiciary has absolute competence different judges and different resources in judging through interpretation the articles in the Election Law vary accordingly with their respective customs in 
adjudicating their ordinary cases. Meanwhile, election matters are a special case (lex specialis) that way judge and interpret a case for achieving substantive justice is not the same deep treatment with other things the judge's decision is requested. Not to mention that the inclusion of disputes over the results of regional head elections handled by the constitutional court has overwhelmed the cases that must be resolved and deemed not in accordance with the speedy trial principle.

Many experts have tried to bring their opinion on how to solve the overlapping case that was settle by constitutional court is by giving some new authority to solve the Regional Head Elections dispute without having to be solved by the constitutional court. This is also in accordance with the concept of the Constitutional Court's decision No. 55 of 2019 that concluded rearrange the standing position of the regional head elections. It means standing position Regional Head Elections still refers to the previous Constitutional Court Decision, namely Decision No. 97 2013. The Constitutional Court's Decision No. 55 of 2019 is ruling that governs concerning the simultaneous implementation of the General Election and Regional Head Elections. The standing position of the regional head elections that is not part of the general election certainly has implications for the design of dispute resolution on the results of the Regional Head Elections. Constitutional Court who has been given the authority to settle disputes over results of the Regional Head Elections only has 4 authorities and 1 obligation in it does not include the authority to settle disputes over election results. Legislators also formulate new norms regarding institutions authorized to resolve disputes over results regional head elections in Article 157 paragraph (1) of Law No 8 of 2015. In this norm, it is determined that the authorities resolving disputes over the results of regional head elections is special judiciary. How and how does the mechanism work the said special judicial body has not yet been regulated.

To answer the various problems above, improvements to the system dispute resolution process and election results need to be done. This can be done by redesigning the system in question. Which is by adopting a special election court that will examine and adjudicate all existing electoral law issues, except disputes over results which remain the authority of the Constitutional Court in accordance mandate of Article 24C paragraph (1) of the 1945 Constitution. If we look at other countries, the Court Special Election Court (Election Court) is also known in the judicial system of several other countries. One of them is English which is set in Representation of People Act 1983. The jam, also in Mexico (The Electoral Tribunal of the Federal Judiciary), Brazil (The Supreme Electoral Court), Panama (Electoral Tribunal), Guatemala (Electoral Tribunal), Bolivia (Electoral National Court), Uruguay (Electoral Court), Peru (National Jury of Elections) and others.
Article 157 paragraph (3) of Law Number 8 of 2015 mandated that before the implementation of regional head elections hold simultaneously nationally, a special judicial body for dispute resolution results regional head elections are certain. To follow up on this mandate, Bawaslu in carrying out function as a special election court at the same time can also acting as a special election judicial body. As a judicial body specifically for elections, Bawaslu only has the authority to complete disputes, excluding election results. While in capacity as a special judicial body for regional elections, in addition to resolving Regional Head Disputes, Bawaslu also acts as a dispute resolution institution election result. So, if in the election Bawaslu only acts as a dispute resolution agency for dispute purposes only, but in Regional Head Disputes, Bawaslu handles all disputes, including disputes over results.

Then how is the design of Bawaslu's authority in settlement? election disputes and disputes? Regarding Regional Head Disputes resolution, either between participants or between participants and the organizers, the authority for the settlement lies with the Provincial Bawaslu. Where, every dispute that arise both in the election of the Governor and the Vice Governor as well as the election of the Regent/Vice Regent and the Mayor/Vice Mayor, the settlement is under the authority of the Provincial Bawaslu.

Regarding the settlement of district/city election disputes, which its authority remains with the Provincial Bawaslu based on the origin: First, the Provincial Bawaslu is permanent, while the Regency/Municipal Panwaslu city is ad hoc; second, the human resources of each district/city uneven, so it is feared that the dispute resolution process will not give maximum result. Regarding the decision of the Provincial Bawaslu in Regional Head Disputes can be appealed to Bawaslu. Where, in context Therefore, Bawaslu acts as an appellate court whose decisions are final and remember in the settlement of election disputes.

As for the dispute over the election results, with the implementation design elections simultaneously nationally, then the authority to settle disputes Election results must also be shared between Bawaslu and Provincial Bawaslu. This must be done to avoid the accumulation of disputes in the level Bawaslu, while there are instruments at the provincial level that can used to examine applications for Regional Head Elections disputes submitted by Regional Head Elections participants.

In this regard, for the settlement of disputes over the election results, the regency/city level is completed by the Provincial Bawaslu. To Provincial Bawaslu decisions can be appealed to Bawaslu with a decision that is final and reminiscent. As for the solution the dispute over the results of the regional election at the provincial level is carried out by Bawaslu with decision which is also final and binding. Thus, the legislators only have to following up on the orders of Law Number 
8 of 2015 by equipping Bawaslu with settlement authority election disputes. where, design settlement authority dispute results in accordance with the description that has been put previous.

\section{CONCLUSION}

Elections are a manifestation and crystallization of democratic values. Indonesia as the 4th largest country in the world practices elections as a form of democracy and a real embodiment of the people. In fact, democracy does not only involve elite participation in Indonesian elections, but the people also have a very important role. The people have the complete advantage to elect leaders not at the national level but also at the local level through presidential elections, legislative elections, and regional head elections. Because the general election which is held every 5 years is very important and essential, the democratic process must really be maintained and considered in order to achieve substantial democracy.

It is undeniable that the implementation of elections always leaves disputes (election residues) that must be resolved by the judiciary as the last institution for justice seekers. In connection with the decision of the Constitutional Court which decides on the implementation of simultaneous elections at the national and local levels, it will have an impact on the resolution of disputes over election results that will occur. Therefore, the possibility of this complexity must be mitigated by creating a dispute resolution system for election results in electoral law politics in Indonesia. This is important considering the limitations of the Constitutional Court if all disputes over national and local election results must be tried in the Constitutional Court, while the Constitutional Court has limitations both in terms of the number of judges and the short time to resolve the results (speedy trial). So, to prevent injustice in the settlement of disputes over results, the idea of a settlement with a model, for example, the process or placing the authority for resolving the dispute to Bawaslu. With the first phase, Bawaslu can effectively and efficiently settle disputes over the results of regional head elections at both the provincial and district/city levels. Furthermore, this idea will be in line and synchronous where Bawaslu as an election supervisory agency has a role to take action against certain election violations and crimes. With the difference in the results of the initial level by Bawaslu, Bawaslu will have room to file a dispute over the results in a structured, systematic and mass (TSM) manner.

\section{REFERENCES}

[1] A., Riswanto. Hukum Partai Politik dan Hukum Pemilu di Indonesia: Pengaruh Terhadap Penyelenggaraan Pemilu Berkualitas dan Sistem Pemerintahan Presidensial Efektif. Yogyakarta: Thafa Media, 2016

[2] J., Asshiddiqie. "Komentar Atas Undang-Undang Dasar Negara Republik Indonesia Tahun 1945.” In Komentar Atas Undang
Undang Dasar Negara Republik Indonesia Tahun 1945, 10. Jakarta: Sinar Grafika, n.d.

[3] K., Fahmi. "Pemilihan Umum dan Kedaulatan Rakyat." In Pemilihan Umum dan Kedaulatan Rakyat, 18. Jakarta: Rajawali Press, 2011.

[4] J., Asshiddiqqie. Pokok-Pokok Hukum Tata Negara Indonesia Pasca Reformasi. Jakarta: Jakarta: PT Bhuana Ilmu Populer, 2007.

[5] D., Indrayana. Indonesia Constitutional Reform 1999-2002: An Evaluation of Constitutional Making in Transition. Jakarta: Kompas, 2008.

[6] S., Isra. Pemilu dan Pemulihan Daulat Rakyat. Jakarta: Themis Press, 2017.

[7] F. Amsari, C. Simabura, K. Fahmi. Pembaharuan Partai Politik di Indonesia: Demokrasi Internal Partai Politik. Jakarta: Instrans Publishing, 2020.

[8] F. Khairul. Pemilihan Umum Dalam Transisi Demokrasi. Jakarta: Rajawali Press, 2016.

[9] Suharizal. Pemilukada: Regulasi, Dinamika, dan Konsep Mendatang. Jakarta: Rajawali Press, 2011.

[10] R. Harun, Pemilu Konstitusional Desain Penyelesaian Pemilu Kini dan Ke depan. Jakarta: Rajawali Press. 2016

[11] Ayon Diniyanto. Mengukur Dampak Penerapan Presidential Threshold di Pemilu Serentak Tahun 2019. Indonesian State Law Review. 1 No. 1 (n.d.): 85.

[12] LBH Yogyakarta. Analisis Undang-Undang Nomor 8 Tahun 2012 tentang Pemilihan Umum Anggota DPR, DPD dan DPRD - LBH Yogyakarta." Access on Juni 5, 2021. https://lbhyogyakarta.org/2013/10/21/analisis-undang-undangnomor-8-tahun-2012-tentang-pemilihan-umum-anggotadewan-perwakilan-rakyat-dewan-perwakilan-daerah-dandewan-perwakilan-rakyat-daerah/.

[13] R. Harun. Rekonstruksi Kewenangan Penyelesaian Perselisihan Hasil Pemilihan Umum. Jurnal Konstitusi Vol 12 No.1. Mahkamah Konstitusi: Jakarta(n.d.): 8.

[14] International IDEA. International Electoral Standards, Guidelines for Reviewing the Legal Framework of Election. Stockholm: International Institute for Democracy and Electoral Assistance. 2002.

[15] R. Surbakti, D. Supriyanto, and T. Santoso. Penanganan sengketa pemilu. Kemitraan bagi Pembaruan Tata Pemerintahan. 2011.

[16] The Regulation of the Constitutional Court (PMK) of the Republic of Indonesia Number 14 of 2008

[17] Law Number 7 of 2017 concerning General Elections.

[18] H. Munte, M. Nasution, P. Tarigan, \& J. Sikumbang. Penyelesaian Sengketa Administrasi Pemilihan Kepala Daerah Berdasarkan Undang-undang Nomor 8 Tahun 2015 Tentang Pemilihan Gubernur, bupati dan Walikota (Studi Putusan Sengketa Administrasi Pemilihan Walikota dan Wakil Walikota di Panwas Kota Pematangsi. USU Law Journal, 5(1), 2017. 164984.

[19] International IDEA. International Electoral Standards: Guidelines for reviewing the legal framework of elections. Publications Office, International IDEA, 2002.

[20] T. Santoso, \& T. Santoso. Penegakan hukum pemilu: praktik pemilu 2004, kajian pemilu 2009-2014. 2006.

[21] Kemitraan. Penanganan Pelanggaran Pemilu. Jakarta: Kemitraan bagi Pembaruan Tata Pemerintahan. 2011. 